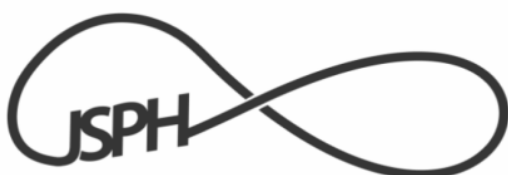

P-ISSN : 2502-7875 E-ISSN : 2527-5879

\title{
ETIKA MASYARAKAT PANDALUNGAN DALAM MERAJUT KEBHINEKAAN (AGAMA)
}

\author{
Abdus Sair \\ Program Studi Sosiologi Faskultas Ilmu Sosial dan Ilmu Politik Universitas Wijaya Kusuma \\ Surabaya \\ Email : syairbook@gmail.com
}

\begin{abstract}
Abstrak
Indonesia adalah negara kesatuan dimana masyarakatnya tumbuh dan besar dengan suku, ras, agama, dan budaya yang berbeda. Kondisi ini terjadi karena ada satu prinsip yang dikenal dengan Bhinneka Tunggal Ika. Namun belakangan, prinsip itu seolah mengalami goncangan karena menguatkan sentimen kedaerahan dan menguatnya pemikiran mayoritas dan minoritas. Seperti munculnya kelompok-kelompok intoleran yang mengancam persatuan dan kesatuan bangsa. Padahal, masalah ini seharusnya telah selesai sejak diproklamirkan kemerdekaan Indonesia di tahun 1945. Karena itu, tulisan ini ingin menyajikan perkara tersebut dari sebuah hasil penelitian. Pengumpulan datanya dilakukan dengan metode kualitatif. Metode ini didahului dengan observasi lapangan kemudian melakukan wawancara mendalam (deepth interview) dan tidak berstruktur (unstructured interview). Hasil penelitian ini menunjukkan bahwa masyarakat pandhalungan di Desa Sumberpakem Kabupaten Jember memiliki etika dan nasrasi sosial yang kuat tentang bagaimana menjaga persatuan dan kesatuan. Mereka memiliki pakem kultural yang disebut dengan sangkolan, yakni sebuah konsep peninggalan leluhur masyarakat tentang bagaimana menghormati dan menghargai masyarakat yang berbeda agama. Selain itu ada konsep taretan dhibik, yakni sebuah perekat antar penduduk. Walau beda agama, mereka menganggapnya taretan dhibik atau saudara sendiri. Untuk merawatnya, mereka juga mengatakan a taretan seterrosah (bersaudara selamanya).
\end{abstract}

Kata kunci : Kebhinekaan, Kearifan Lokal, Masyarakat Pandhalunga

\section{PANDALUNGAN COMMUNITY ETHICS IN FRAMING DIVERSITY (RELIGION)}

\begin{abstract}
Indonesia is a unitary country whose people evolve and live in different tribes, races, religions, cultures and languages. This condition occurs as there is one principle known as Bhinneka Tunggal Ika. This principle, hoever, seems to confront or experience "turbulance" along with teh encreases of regional sentiments and majority and minority disparities. Fot instance, the emergance of intolerant groups has threatened the unity of nation. This problem that should be solved sice the proclamation of Indonesian independence in 1945 emerged due to the fact that the goverment has not touched the local wisdom of the community on how to maintain unity. Therefore, this papes aims at presenting the results or research ( $a$ case) with qualitiative methods. The data collection is carried out through field observation and indepth interview (unstructure interview). The results of this study indicate that the "pandhalungan community" in Sumberpakem Village Jember District has a strong social integrity about how to maintain unity. They have a cultural grip called a sangkolan, which is a concept of the ancetral heritage of the community on how to respect and appreciate people of difference religions. Morover, there is also the concept of " taretan dhibik", which is a glue or tie among residens. Although they have different religions, they consider others as "taretan dhibik" or they brothers. They also say "ataretan saterrosah" (brothers forever)
\end{abstract}

Keywords : Diversity, Local Wisdom, Pandalungan Community 


\section{PENDAHULUAN}

Indonesia adalah negara dengan penduduk sangat berar. Hingga tahun 2019, penduduk Indonesia telah mencapai 269 juta jiwa (Worldometer, 2019). Jumlah ini tersebar di berbagai pulai di tanah air. Sebagai negara besar, Indonesia telah menjadi negara dengan keragaman paling banyak di dunia. Berbagai suku, bahasa, budaya, agama dan adat istiadat menyatu dalam bingkai Negara Kesatuan Republik Indonesia (NKRI). Penyatuan ini merupakan kunci yang diikat oleh satu semboyan paling populer yang disebut dengan Bhinneka Tunggal Ika. Keragaman tersebut kemudinan terpelihara setelah sebelumnya selama kurang lebih 200 tahun lamanya dijajah Belanda. Baru setelah memasuki abad ke 20, para tokoh nasional mencoba menyatukan kembali dengan melahirkan semboyan tersebut untuk kejayaan dan persatuan Indonesia (Vlekke, 2018).

Namun, harus diakui, pasca kemerdekaan Indonesia, keragaman itu mulai sering muncul masalah. Percekcokan atau konflik antar suku, bahkan agama seringkali mewarnai media nasional. Salah satu sebab adalah menguatnya sentimen kedaerahan dan kuatnya pemikiran mayoritas dan minoritas (Hamdi, 2010). Yang terjadi kemudian, tenun persatuan itu seolah robek dengan pemandangan bolong di tengahnya. Lebih-lebih setelah munculnya perubahan hukum pemilu, masalah persatuan ini tereduksi oleh perilaku elit politik yang memanfaatkan keadaan untuk kepentingan politik. Padahal, masalah ini seharusnya telah selesai, mengingat kemerdekaan Indonesia hampir genap 100 tahun lamanya.

Masalah lain yang sangat krusial adalah semakin banyaknya sikap dan perilaku intoleran di berbagai daerah, serta berseminya kelompokkelompok intoleran yang mengancam persatuan dan kesatuan bangsa. Kelompok tersebut berkecenderungan kuat untuk selalu membuat "identitas tunggal", yakni menyeragamkan perbedaan yang sudah ada (Redaksi, $2008: 5$ ). Padahal yang demikian ini berhadapan dengan realitas kebangsaan Indonesia yang multi budaya dan multi agama. Serta berhadapan dengan konsensus para leluhur bangsa yang telah sepakat bahwa Indonesia adalah negara kesatuan yang terdiri dari suku, agama, ras, budaya, dan bahasa yang membentang dari ujung Aceh hingga ujung Papua.

Tokoh kenamaan seperti Nur Cholish Majid (Cak Nur) dan Abdurrahman Wahid alias Gus Dur sudah lama mengingatkan agar masalah di atas diantisipasi dengan gagasan yang lebih inklusif, pluralis, dan prososial (Wahid dalam Madjid, dkk, 2017: 1). Gagasan itu tidak hanya disampaikan melalui rujukan buku-buku ilmiah, namun juga dirujuk dari masyarakat lokal yang memiliki gagasan hebat soal merajut kebhinekaan budaya dan agama. Gagasan tersebut lebih humanis dan sesuai dengan fakta sosial keagamaan dan kultural Indonesia. Yakni sebuah gagasan yang tumbuh berdasarkan pada fakta kebudayaan dan keagamaan yang memiliki akar yang kuat. Bukan berdasarkan pada gagasan impor nir kultural.

Gagasan itu seharusnya telah dipelajari dari sumber-sumber masyarakat yang memiliki etika sosial tentang bagaimana menjaga persatuan dan kesatuan. Dalam konteks ini pemerintah sejatinya menjadi garda paling depan mempelajari masyarakat lokal itu yang memiliki cara pandang moderat. Cara pandang tersebut tentu sangat dibutuhkan ditengah maraknya kelompok-kelompok yang selalu mengatasnamakan mayoritas. Karena itu, keberadaan masyarakat tersebut sangatlah penting dipelajari karena keberadaanya perlu menjadi pola bagi kehidupan masyarakat di tempat lain. Masyarakat yang demikian itu harus diakui membentang dari ujung barat Aceh hingga ujung timur Papua. Di daerah Sumatera Utara misalnya ada wilayah Pematang Siantar, di Jawa ada Salatiga, di Kalimantan ada Palangkaraya dan sebagainya. Daerah-daerah tersebut selama ini dianggap mampu bersatu, meredam konflik atas nama agama dan kebudayaan. Salah satu sebabnya karena mereka memiliki semangat toleransi yang kuat. Setara dengan Institut dalam satu penelitiannya juga menyebutkan nama daerah yang disebutkan di atas termasuk dalam 10 kota paling toleran di 
Indonesia pada tahun 2015 (Tempo.co, 17/11/2015). Walaupun hasil penelitian itu bukan secara kualitatif, namun indikator yang dibuat menegaskan bahwa di daerah masih banyak masyarakat yang memiliki cara berfikir moderat, tidak membedakan mana mayoritas dan mana minoritas.

Terkait dengan itu, maka dalam tulisan ini ingin menyajikan perkara tersebut dengan mengetengahkan sebuah gambaran daerah dimana masyarakatnya memiliki cara pandang moderat. Mereka hidup dengan rukun walaupun didalamnya terdapat perbedaan yang bermacammacam. Kondisi itu dapat dilihat dari kehidupan masyarakatnya yang aman. Tidak ada konflik horizontal yang disebabkan oleh perbedaan agama mayoritas dan minoritas. Mereka adalah orang desa yang secara administratif berada di Desa Sumberpakem. Desa ini mengabarkan bahwa dibalik kehidupan sosialnya, terdapat semacam narasi yang penting untuk dipelajari, direnungkan bahkan dipahami, yakni terkait dengan cara berfikir yang seimbang. Di desa ini berkarakter pandhalungan (Madura-Jawa) yang bercorak agraris serta jauh dari perkotaan. Disebut demikian karena akses menuju desa ini cukup jauh dari Kota Jember, yakni $38 \mathrm{Km}$ jaraknya. Masyarakatnya memanfaatkan ekologi alam untuk memenuhi kebutuhan sehari-hari. Terletak di kaki gunung Raung di sebelah sisi timur. Karena kondisi wilayah tersebut mereka memanfaatkan kesuburan tanahnya yang merupakan hasil dari gejala vulkanik dengan mengembangkan pertanian dan perkebunan. Mereka juga memanfaatkan aliran sungai sebagai irigasi untuk mengairi sawah-sawahnya untuk pertanian padi sebagai pemenuhan kebutuhan hidupnya.

Namun dalam urusan toleransi, mereka justru lebih matang. Mereka hadir sebagai entitas yang mampu mengelola kehidupannya secara aman dan damai. Kebhinekaan (agama) bagi mereka dipahami sebagai jalan hidup (way of life) yang dipancarkan dalam kehidupan sehari-hari. Tak ada kekerasan, apalagi konflik atas nama agama. Mereka sangat inklusif dan pluralis. Jalan ini dipilih bukan dengan tujuan untuk mengaburkan agama. Namun lebih karena mereka ingin saling menghormati terhadap masyarakat atau kelompok keagamaan lain yang faktanya memiliki akar keagamaan yang sama. Mereka merawatnya dengan kebudayaan pandhalungan sebagai bentuk kearifan lokal.

\section{METODE PENELITIAN}

Tulisan ini merupakan hasil penelitian yang dilakukan secara kualitatif, yakni sebuah penelitian yang berusaha untuk menggali informasi tentang persoalan yang dijadikan topik penelitian dengan mengutamakan data-data verbal. Namun dalam hal ini juga berusaha untuk menggambarkan secara menyeluruh fenomena yang terjadi melalui pertimbangan kontekstual, yakni mengeksplorasi konteks historis, sosial, budaya, ekonomi dan politik. Teknik pengumpulan datanya dilakukan dengan observasi lapangan atau pengamatan secara langsung, serta melalui wawancara tidak berstruktur (unstructured interview) dalam deepth interview (wawancara mendalam). Wawancara dilakukan terhadap tokoh kedua agama (Islam dan Kristen), Kepala Desa dan masyarakat umum yang mengerti tentang hubungan kedua agama di atas. Analisis data dilakukan secara kualitatif dengan metode interaktif, yakni melalui jalur reduksi data, penyajian data, dan penarikan kesimpulan. Proses analis data dilakukan bersamaan dengan proses pengumpulan data itu sendiri dan terus berjalan selama proses penelitian berlangsung.

\section{HASIL DAN PEMBAHASAN}

\section{Siapa Masyarakat Pandhalungan?}

Hingga sekarang belum ada penjelasan yang benar-benar dapat memberikan gambaran yang menyeluruh tentang siapa masyarakat pandalungan sebenarnya. Beberapa tulisan yang menjelaskan perkara ini adalah tulisan Ayu Sutarto (2006), Mudji Hartono (2010), Bambang Wibisono dan Akhmad Haryono (2016), Ikwan Setiawan (2016), M Ilham Soebazary (2017). Beberapa tulisan di atas belum ada kata sepakat tentang siapa masyarakat pandalungan tersebut. Namun secara sosiologis mereka setuju bahwa masyarakat pandalungan merupakan masyarakat hibrid akibat terjadinya percampuran dua 
kebudayaan dominan, yakni Madura dan Jawa sekaligus Islam di kawasan Tapal Kuda. Kawasan Tapal Kuda merupakan kawasan yang secara geopolitik dan geososio-kultural berada di Provinsi Jawa Timur yang membentuk lekukan mirip ladam atau kasut besi kaki kuda. Kawasan ini memiliki karakteristik tertentu dan telah lama menjadi kantong pendukung Islam kultural dan kaum abangan.

Selaras dengan tulisan di atas, Kristanto dan Wahyu (Kompas, 21/7/2008) dalam satu liputannya memberikan karakteristik bahwa masyarakat pandhalungan lebih bercorak agraris-egaliter, agresif, ekspansif, dan memiliki solidaritas tinggi, namun tetap agamis yang menempatkan pemimpin agama (kiai) sebagai tokoh sentral. Sebagaimana yang telah diketahui, masyarakat pandhalungan memang menempatkan kiai sebagai tokoh agama yang sangat dihormati. Posisinya seringkali melebihi pemimpin kepada daerah. Ini dapat dilihat dari ketika harus memutuskan sesuatu. Umumnya harus menunggu petuah dari sang kiai. Demikian juga, penghormatan mereka terhadap para kiai biasanya direpresentasikan dengan memampang foto-foto kiai di dalam rumahnya dibandingkan dengan memampang foto kepada daerah atau bahkan foto Presiden dan Wakil Presiden sekalipun. Foto kiai dianggap dapat membawa berkah dan bisa mendapatkan syafaatnya. Oleh karena itu, masyarakat pandhalungan juga sering disebut dengan masyarakat Islam kultural yang taat. Walau demikian, ada sedikit pergesesan terhadap penempataan kiai sebagai tokoh sentral tersebut akibat kebijakan politik yang sangat liberal. Yakni munculnya kebijakan pemilihan kepala daerah secara langsung. Para kiai yang terlibat dalam proses tersebut seringkali mengalami "perceraian" dengan sesama kiai yang berefek pada masyarakat di bawahnya (Turmudi, 2004 : 159).

Dalam penggunaan kata pandhalungan sebagaimana disebut di atas ditengarai karena kebudayaan masyarakat di wilayah ini dianggap terbentuk oleh pertemuan dari berbagai etnik kebudayaan, sehingga melahirkan kebudayaan baru yang disebut pandhalungan. Beberapa akademisi seperti Ayu Sutarto mengutip Prawiroatmodjo (1985:100) tentang kata pandhalungan tersebut yang dianggap berasal dari bentuk dasar bahasa Jawa yaitu "ndhalung" yang artinya adalah "periuk besar". Kemudian dihubungkannya dengan wilayah ini sebagai tempat dimana kebudayaan dari berbagai etnik berkumpul. Sementara arti dari pandhalungan sendiri jika dirujuk dari Bausastra Jawa Kamus Bahasa Jawa Online memiliki arti guneman ora unggah-unggahe yang berarti berbicara/berkata dengan tiada tentu adabnya/sopan-santunnya.

Pengertian ini oleh Soebazary (2017) juga masih dianggap kurang tepat karena melihatnya dari satu sisi, yakni sisi orang kulon. Sisi yang lain tidak dilihat, seperti aspek etika, cara bercocok tanam, bertetangga, dan sebagainya. Namun dari sisi bahasa memang demikian. Bahwa masyarakat pandhalungan memang menggunakan bahasa yang agak kasar (ngoko) atau struktur gramatikanya belum mapan seperti ditandai dengan intensitas inferensi leksikal dan gramatikal. Ketidakmapanan ini menurut Kusnadi (2001) yang dikutip Ayu Sutarto (2006) terjadi karena interaksi sosial dalam kehidupan masyarakat dilakukan oleh masing-masing pemilik kebahasaan yaitu Jawa dan Madura, kedudukannya sama-sama kuat atau sama dominan.

Tetapi menurut Wibisono dan Haryono (2016 : 9-14) bahasa sehari-hari masyarakat pandhalungan sesungguhnya lebih banyak berbahasa Madura yang bercampur dengan bahasa Jawa. Jika dilihat dari ciri fonologis yang tampak menonjol adalah logatnya. Dalam obrolan sehari-hari misalnya, masyarakat pandhalungan masih berlogat bahasa Madura baik ketika berbahasa Indonesia maupun ketika berbahasa Jawa. Sebagai contoh ketika harus mengemukakan struktur fonologis [me] dalam bahasa Indonesia, orang-orang pandhalungan cenderung mengungkapkannya dengan [mi]. Akibatnya kata [merah] menjadi [mira], kata [melon] menjadi [milon]. Demikian juga pengucapan bunyi $U$ yang terdapat pada rangkaian fonologis [nur], [tu], [ku], dan [nung], mereka mengucapkannya dengan [o]. Sehingga kata Nur Jannah menjadi [Nor Jannah], tulung 
menjadi [Tolong], kuning menjadi [Koneng], campur menjadi [Campor].

Lebih jauh menurut Wibisono dan Haryono, orang pandhalungan sering mereduksi atau memotong kata ulang utuh menjadi kata ulang tidak utuh, seperti pada kata Alon-Alon menjadi Lon-Alon, Tiyang-Tiyang menjadi Yang-Tiyang, Mlaku-Mlaku menjadi Ku-Mlaku, Konco-Konco menjadi Co-Konco, Kanak-Kanak menjadi Nak-Kanak. Bahkan dalam rangkaian kata yang lain, orang Pandhalungan banyak menukar awalan [ter] dengan konfiks [ke-an], seperti kata tertidur menjadi ketiduran, terlupa menjadi kelupaan, terbangun menjadi kebangunan. Disamping itu ada juga awalan [ber] ditukar menjadi akhiran [an], seperti kata bertetangga menjadi tetanggaan, berteman menjadi temanan.

Namun, jika dilihat dari karakternya, secara umum masyarakat pandhalungan lebih bersifat permisif tetapi agak temperamental. Mereka lebih menerima dari pada menolak. Karena itu di wilayah ini tidak pernah terjadi konflik besar akibat perbedaan etnis atau kelompot etnik. Jika ada perbedaan, masyarakat pandhalungan akan mengatakan gak usah dibesar-besarkan, ayo diselesaikan ya opo enake. Masyarakat pandhalungan juga tidak suka berbasa basi, apapun yang menjadi ketidaksukaannya, akan segera disampaikan. Demikian juga jika mereka suka, maka akan segera mengungkapkannya. Ini mirip dengan karakter masyarakat di wilayah Arek.

Karena itu secara umum Ayu Susarto (2006) membuat ciri-ciri tentang masyarakat pandhalungan sebagai berikut; (1) Sebagian besar agraris tradisional, berada di pertengahan jalan antara masyarakat tradisonal dan industri; tradisi dan mitos mengambil tempat yang dominan dalam kesehariannya, (2) Sebagian besar masih terkungkung oleh tradisi lisan tahap pertama (primary orality) dengan ciriciri suka mengobrol, ngrasani (membicarakan aib orang lain), takut menyimpang dari pikiran dan pendapat yang berlaku umum, (3) Terbuka terhadap perubahan dan mudah beradaptasi, (4) Ekspresif, transparan, tidak suka memendam perasaan atau berbasa basi, (5) Paternalistik: keputusan bertindaknya mengikuti keputusan yang diambil oleh para tokoh yang dijadikan panutan, (6) Ikatan kekeluargaan sangat solid sehingga penyelesaian masalah seringkali dilakukan dengan cara keroyokan, (7) Sedikit keras dan temperamental.

\section{Setting Sosial Masyarakat Pandhalungan}

Satu dari sekian banyak daerah pandhalungan yang bisa dijelaskan adalah Desa Sumberpakem. Desa Sumberpakem memiliki penduduk dengan jumlah sekitar 6.084 jiwa. Mayoritas dari mereka bekerja sebagai petani, buruh petani dan perkebunan. Mereka berasal dari suku Madura lalu bertemu dengan suku Jawa di ujung timur pulau Jawa. Kemudian tinggal di beberapa daerah salah satunya di Jember. Pertemuan ini tidak lepas karena kebijakan dibukanya perkebunan swasta pada abad ke 19 oleh Pemerintah Hindia Belanda konsekuensi dari diberlakukannya UndangUndang Agraria tahun 1870, setelah sebelumnya Pemerintah Hindia Belanda menerapkan apa yang disebut dengan sistem tanam paksa (cultuurstelsel). Masyarakat suku Madura berbondong-bondong bermigrasi ke Jember melalui Panarukan dan Bondowoso, setelah sebelumnya mereka menyeberangi laut dengan perahu kecil dari tanah kelahirannya Madura. Mereka bermigrasi karena kondisi di Madura yang miskin dan sulitnya pekerjaan. Mereka menetap dan berkeluarga di wilayah ini dan berjumpa dengan orang Jawa, lalu melahirkan kebudayaan baru yang dikenal dengan budaya pandhalungan.

Masyarakat pandhalungan di desa ini dikenal sangat agamis (Islam) dan memiliki ketaatan pada tokoh agama (kiai). Namun mereka lebih terbuka dengan perbedaan budaya dan agama. Karakter yang berbeda dengan masyarakat suku Madura di tanah Madura ini terjadi karena mereka ada proses asimilasi dengan karakter masyarakat Jawa. Dari segi kuantitas mereka beragama Islam dengan jumlah mencapai $95 \%$. Sementara sisanya beragama Kristen. Walau demikian, mereka mampu hidup bersama dengan nilai-nilai toleransi yang kuat. Mereka simpati, empati, dan peduli terhadap 
keanekaragaman kultural dan agama. Bahkan mereka juga mau hidup bersama, saling percaya dan saling mendukung (ko-eksistensi dan proeksistensi) (Mamuaya dan Sair, 2017). Bentuk tindakan mereka itu adalah kemampuan berfikir dan berperilaku bijak (wisdom) dengan sesama. Semua itu terjadi karena mereka memiliki akar kebudayaan yang sama (Madura dan Jawa) sekaligus juga karena kearifan lokal diturunkan dari leluhur mereka melalui pengetahuan organik.

Sebagian besar masyarakat pandhalungan ini memiliki pandangan bahwa kebhinekaan (agama) bukanlah perkara yang sangat serius. Kebhinekaan adalah hukum Tuhan yang harus dijalani lalu dirawat dengan baik. Pandangan ini tumbuh sesuai dengan konteks sosial dan lingkungan mereka. Mereka sama-sama dibesarkan dari komunitas masyarakat dengan kebudayaan dominan, Madura dan Jawa. Itu sebabnya walau Islam mayoritas dan eksis jauh sebelum Kristen masuk, mereka tidak merasa resisten terhadap proses kristenisasi di wilayah ini yang dimulai sejak abad ke 19. Mereka saling menghormati hingga kemudian menjadi komunitas Kristen yang kuat sampai sekarang.

Sebagaimana diketahui, Kristen masuk di wilayah ini pada abad ke 19. Dibawa oleh Java Comitee. Sebuah lembaga Pengabaran Injil atau zending yang berdiri di Belanda pada tahun 1855 (Sihombing, 2009 : 27), berfungsi sebagai pengabaran Injil di Indonesia, khususnya di tanah Jawa dan Madura. Java Comitee bukanlah lembaga milik Pemerintah Hindia Belanda. Namun lembaga swasta yang didirikan oleh perseorangan. Akan tetapi, Pemerintah Belanda mendukung usaha zending karena kepentingan politis. Saat itu, tokoh dan masyarakat Islam di tanah Jawa sangat benci terhadap Belanda, namun permisif dengan orang-orang Kristen. Karena itu Pemerintah Belanda mendukung zending itu untuk kepentingan politik Belanda. Pengabaran Injil dilakukan di daerah-daerah Indonesia. Daerah yang masyarakatnya sudah Islam tidak diperkenankan zending masuk karena dapat menimbulkan keributan dan kemarahan para ulama Islam. Daerah yang diperbolehkan adalah yang masyarakatnya memiliki pemahaman agama rendah, agama tradisional atau agama suku.

Di ujung timur pulau Jawa Timur, Java Comitee khusus melakukan mengabaran Injil di daerah Slateng, Kayu Mas, Bremi, dan Pulau Kangean (timur Pulau Madura) (Julailah, 2015 : 2). Besar kemungkinan daerah-daerah tersebut dianggap memiliki masyarakat dengan pemahaman agama (Islam) yang belum kuat. Termasuk di pulau Madura. Kristenisasi dilakukan dengan kehadiran beberapa orang zending pertama (resmi) yang tinggal di Madura. Pada tahun 1864 misalnya, ada Pendeta Samuel Harthoorn (orang Belanda) beserta istrinya yang menetap di Pamekasan untuk melakukan kristenisasi. Namun usaha ini gagal karena pada tahun 1868, rumahnya dikepung masa dan istrinya dibunuh. Pada tahun 1880 juga ada Pendeta muda yang pandai, bergelar doktor dan bisa berbahasa Madura, bernama J. P. Esser. Namun usahanya juga gagal karena ditolah oleh masyarakat Madura. Itu sebanya Esser segera keluar meninggalkan Madura dan tinggal di Bondowoso, kemudian pindah ke Sumberpakem (Jember) (wikipedia.org).

Sejak itu kristenisasi pertama dimulai di daerah Sumberpakem, dan J. P. Esser menjadi orang zending pertama yang melakukan kristenisasi di wilayah Jember utara ini. Besar dugaan, masyarakat Sumberpekem saat itu belum memiliki Sumber Daya Manusia (SDM) yang mapan, pendidikan dan kesehatan yang rendah, dan masyoritas dari mereka berasal dari suku Madura yang bermigrasi ke Jember. Mereka juga bekerja sebagai buruh perkebunan dan pertanian. Namun mereka tidak terlalu resisten karena memiliki karakter berbeda dengan orang Madura di tanah Madura. Faktor lingkungan, keadaan alam dan status mereka sebagai orang migran mengkonstruksi mereka menjadi masyarakat yang lebih permisif. Mereka lebih menerima terhadap kedatangan J. P. Esser yang memiliki kepercayaan berbeda. Cara mereka menolak kegiatan J. P. Esser-pun juga dilakukan dengan cara yang lebih sopan $(s h o f t)$. Keadaan ini yang barangkali membuat J. P. Esser lebih betah tinggal di Sumberpakem dari pada memilih tinggal di Madura. 
Di Sumberpakem, J. P. Esser melakukan Pengajaban Injil melalui dua jalur, yakni kesehatan dan pendidikan. Ia mendirikan balai pengobatan semacam poliklinik. Masyarakat yang mau memeriksa kesehatannya harus mendengarkan dulu kesaksian dan pengabaran Injil. Namun, usaha ini lambat laut mundur karena masyarakat hanya mau menerima pelayanan kesehatan dan enggan mendengarkan kesaksian darinya. Selain itu, J. P. Esser juga mendirikan sekolah dasar Kristen untuk meningkatkan Sumber Daya Manusia. Ini adalah cara kedua yang dilakukan J. P. Esser agar masyarakat lebih mudah menerima pengabaran Injil. Upaya ini juga berjalan lancar, bahkan diawal pendiriannya, sekolah tersebut diminati masyarakat. Walau kemudian mengalami kemunduran yang sama karena masyarakat mulai jenuh dengan sekolah yang harus mengengarkan kesaksian dan pengara Injil dari J. P. Esser (Julailah, 2015 : 2).

Akan tetapi, upaya J. P. Esser di atas tidak sia-sia, ia berhasil mengkristenkan salah satu muridnya bernama Sadin, yang kini dikenal dengan nama Ebing. Ebing adalah anak pertama Sadin. Dalam tradisi Madura, nama anak pertama selalu menjadi panggilan orang tuanya. Ebing kemudian dibabtis oleh J. P. Esser pada tanggal 23 Juli 1882 dan menjadi orang Kristen pertama dari suku Madura di kawasan Sumberpakem. Tanggal 23 Juli 1882 kemudian ditetapkan menjadi tanggal lahirnya Jamaat Desa Sumberpakem. Sebagai orang kristen baru, Ebing menjalankan agamanya dengan taat, bahkan ia juga membantu J. P. Esser melakukan pengabaran Injil. Pada tahun 1884, ia berhasil mengkristenkan keluargnya yang juga berasal dari suku Madura.

Ajaran Kristus yang dianut oleh Ebing dan keluarganya ini terus dirawat hingga sekarang, dimana umurnya sudah 135 tahun. Para penganutnya juga kurang lebih 100 kepala keluarga. Mereka memiliki Gereja Kristen Jawi Wetan (GKJW). Walau nama Gerejanya berbahasa Jawa, namun penganutnya adalah orang Madura. Yang menarik masyarakat Kristen di wilayah ini memiliki Alkibat berbahasa Madura yang disebut dengan Alketab,
E Dhalem Basa Madura. Alkitab ini diterjemahkan secara bertahap dan dicetak pada tahun 1994 dengan ketabalan 512 halaman. Demikian juga, semua tata cara ibadahnya yang dilakukan setiap hari minggu juga menggunakan bahasa Madura. Bahkan di sebuah mimbar Pendeta, "Pengakuan Iman Rosuli" yang sering diucapkan oleh umat Kristiani juga ditulis dengan berbahasa Madura seperti berikut ini;

(1) Kaula parcaja dhe' ka Alla, enggi paneka Rama se Maha Kobasa, se ampon amorba langnge' kalaban bumi, (2) Kaula petaja dhe'ka Yesus Kristus, Potrepon se settong, Pengeran kaula.(3) Se epa-adheg bi' Roh se kudhus serta ebabaragi bi' praban Mariya, (4) Se ampon kenging sangsara nalekana Pontius Pilatus ethang-thang, laju seda, pas ekoburagi, toron ka alam epon sreng mate. (5) Ka tello' are epon bungo pole dhari seda. (6) Laju ngabang dha'ka Sowarga, alonggu e kanganepon Allah Rama se Maha Kobasa (7) Dhari ka' dhissa badhi rabuwa angadilanna sedajana oreng se odhi' kalaban se ampon mate. (8) Kaula percaja dha' ka Roh se Kodhus. (9) Kaula parcaja badha settong podhuepon sadajana oreng Kristen se socce, panapa pole dha'karapenepon oreng socce paneka. (10) Saporaepon dusa, (11) Jagaepon oreng mate (12) Kaodhi'an se langgeng sanemanena.

[(1) Aku percaya kepada Alaah Bapa yang maha kuasa Khalik langit dan bumi, (2) Dan kepada Yesus Kristus Anaknya yang tunggal, Tuhan kita, (3)Yang dikandung dari Roh Kudus, lahir dari anak dara Maria, (4) yang menderita dibawah pemerintahan Pontius Pilatus disalibkan, mati dan dikuburkan turun ke dalam kerajaan maut, (5) Pada hari yang ketiga bangkit pula dari antara orang mati, (6) Naik ke surga, duduk disebelah kanan Allah, Bapak yang maha kuasa, (7) Dan akan datang dari sana untuk menghakimi orang, yang hidup dan yang mati, (8) Aku percaya keda Roh Kudus, (9) Gereja yang kudus dan am, persekutuan orang kudus, (10) Pengampunan dosa, (11) Kebangkitan daging, (12) Dan hidup yang kekal]

\section{Etika Masyarakat Pandhalungan}

Penjelasan tentang setting sosial masyarakat pandhalungan di atas memberi gambaran yang jelas bahwa mereka unik, mampu hidup bersama dalam komunitas 
berbeda. Masyarakat Islam dan Kristen di desa ini bisa hidup rukun dengan suasana yang aman. Perbedaan yang muncul di tengah masyarakat tersebut bukan sebagai alergi. Perbedaan dimengerti sebagai kekuatan untuk saling melengkapi, berfungsi sebagai pengawas sekaligus sebagai penekan kemungkinan terjadinya pelanggaran terhadap norma, nilainilai dan peraturan yang dibangun secara sosial. Konsekuensi dari pemahaman tersebut adalah kehidupan harmoni yang dibingkai oleh pemahaman kultural dan menjadi narasi yang sangat kuat.

Pemahaman itu tumbuh seiring dengan tumbuhnya cara pandang masyarakat. Mereka mengkonstruksikannya menjadi pengetahuan tentang bagaimana merajut kebhinekaan (agama) yang di dalamnya mengandung nilainilai luhur dan lokal seperti keadilan, kepekaan sosial dan demokratis. Menurut Mansour Fakih (2011 : 66-67), kondisi itu umum terjadi pada masyarakat pedesaan (organik). Mereka memiliki pengetahuan yang baik, memahami tradisi dan adat, ada pemberdayaan terhadap nilai-nilai yang sudah adil, serta melakukan transformasi budaya didalamnya. Demikian juga pada masyarakat pandhalungan di desa ini memiliki narasi yang sama, bahwa mereka menciptakan hubungan yang setara, mendasar, baru dan baik. Cara ini mereka lakukan dengan memberi ruang kepada sesama untuk menciptakan sejarah dan eksistensi masingmasing. Mereka saling mengapresiasi antara satu dengan lainnya terutama terhadap keyakinan dan tradisinya, dan menjamin setiap mereka "hak hidup secara bebas yang bertangungjawab", serta selau menghargai kemanusiaan. Karena itu, dalam konteks ini, etika masyarakat pandhalungan dapat dilihat melalui kerukunan beragama yang diwujudkan dalam praktek sosial sehari-hari, dimana nilainilainya berupa cinta kepada Tuhan, tanggung jawab, kasih sayang dan peduli, adil dan saling menghormati. Semua itu mereka rangkum dengan istilah-istilah lokal yang unik dan khas, serta memiliki kekuatan untuk mengikat, sebagai berikut;

\section{A. Sangkola}

Istilah ini merupakan istilah umum yang dipakai oleh masyarakat untuk menyebut peninggalan leluhurnya. Sangkolan digunakan untuk merujuk pada sebuah warisan ide atau gagasan soal bagaimana mereka menjaga persatuan dan kesatuan. Pada masyarakat Madura di pulau Madura, sangkolan diartikan sebagai harta benda atau pusaka dari orang tua kepada anak-anaknya ketika masih hidup dan dilaksanakan sesudah orang tuanya meninggal dunia. Pemahaman ini juga serupa dengan warisan tanah dari orang tuanya ke anakanaknya. Dalam konteks ini, sangkolan dimaknai sebagai konsep dasar mengenai peninggalan leluhur masyarakat pandhalungan tentang bagaimana menjaga persatuan dan kesatuan, saling menghormati dan menghargai. Melalui definisi ini, sangkolan tidak hanya sebagai barang atau benda, namun lebih dimaknai sebagai ajaran yang diturunkan melalui generasi ke generasi.

Sebagai ajaran, sangkolan dipelajari melalui pendidikan alamiah (organik). Orang tua dan tokoh masyarakat menjadi agen pengetahuan mengenai perihal tersebut. Dalam konteks ini, sangkolan kemudian bersifat kultural. Karena itu, setiap mereka terutama orang tua merasa bertanggungjawab untuk meneruskan pesan kebudayaan itu dengan menyampaikan nilai-nilai kebersamaan kepada anak cucu mereka.

Nilai-nilai yang terkandung dalam sangkolan itu adalah cinta kepada Tuhan, tanggung jawab, kasih sayang dan peduli, adil dan saling menghormati. Sebagai wujud tersebut mereka kemudian beragama dengan hati. Mereka berusaha menciptakan persatuan dengan saling menghormati dan bertanggungjawab. Menghormati adalah tindakan yang paling mulia dari mereka kepada agama yang lain. Kepada umat Kristiani misalnya, masyarakat Islam menyatu dan tak ada sikap mencurigai karena mereka yakin masyarakat Kristen sedang menjalankan ibadah dan kepercayaannya sama dengan umat Islam pada umumnya, hanya praktek dan caranya berbeda. Saling menghormati adalah bentuk ajaran agama yang 
mereka yakini melalui pemahaman sosial dari gagasan dan perilaku orang tua atau sesepuh mereka. Pemahaman itu mereka terima melalui proses turun temurun.

Sebaliknya, sebagai orang Kristen (minoritas), masyarakat Kristiani tidak merasa alergi dengan Islam. Masyarakat Islam dianggap umat Tuhan dengan tafsir berbeda. Sebagai sesama umat Tuhan, maka mereka membangun komunitas yang setara tanpa ada sekat sosial akibat kepercayaan yang berbeda. Mereka menyatu, bahkan melintas batas ((passing over). Melintas batas yang dimaksud adalah, mereka saling menyapa dalam konteks ritual kebudayaan. Seperti slametan bersama, tahlilan bersama dan sebagainya. Ini bukan keanehan, melainkan sebagai ketakjuban dan keelokan dari Tuhan tentang keberbedaan. Menurut Fajar Wicaksono, seorang Pendeta Gereja setempat, ini adalah cahaya Ilahi tentang keberagaman. Ini adalah warisan leluhur yang tidak ditemukan di masyarakat lain.

Alhamdulillah selama 5 tahun ini saya mendapat berkat untuk melihat, justru ketakjuban-ketakjuban, keelokan dari Tuhan bagaimana indahnya suatu keberagaman dan keberbedaan. Justru saya melihat kekayaan nur ilahi dari Tuhan dalam keberbedaan ini. Dan Insya Allah apa yang sudah ada, warisan leluhur ini, karena ikatan kekerabatan persaudaraan ini mendapat ridho dari Tuhan. Berlangsung tanpa batas waktu (Fajar Wicaksono, 20 Juni 2017).

Melintas batas yang lain yang dapat dilihat adalah menyatunya beberapa keluarga di desa Sumberpakem. Dalam satu rumah tangga misalnya dihuni oleh beberapa kepala keluarga atau beberapa orang yang agamanya berbeda (Islam-Kristen). Mereka mampu hidup bersama tanpa ada gejala disharmoni. Sebagai contoh, sekretaris GKJW Sumberpakem, ibunya adalah Nasrani, tetapi mereka tinggal dalam satu atap dengan Pamannya, yang notabene merupakan tokoh Islam setempat (yakni Takmir Masjid Darul Ulum di desa itu). Contoh ini hanya sebagian kecil dari contoh keluarga yang lain. Kondisi tersebut umum terjadi pada masyarakat Sumberpakem. Dimana mereka menganggapnya hal yang biasa, bukan fenomenal atau bombastisme. Ini adalah kelaziman yang terjadi sejak puluhan tahun lamanya. Ini terjadi juga bukan karena kebetulan, melainkan karena ada kekerabatan sebagai kunci diantara mereka, sehingga perbedaan agama tak pernah melahirkan konflik bahkan mampu diredam hingga ke titik yang paling dasar.

Karena itu, kebhinekaan (agama) dianggap bukanlah perkara serius bagi mereka. Kebhinekaan adalah kekayaan kultural. Untuk kelangsungan itu, mereka merawatnya dengan baik. Mereka saling membantu dan berbagi hingga melintas batas keagamaan. Mereka saling percaya dan meredam kecurigaan. Saling bertanggungjawab atas keberadaan masingmasing, hidup bersama dengan ikatan keluarga yang kuat menjalankan ibadah masing-masing. Namun dalam konteks kebudayaan, mereka menjalankan secara bersama. Semua itu mereka rawat dengan adat istiadat, dengan budaya lokal yang memiliki nilai (value) agung melengkapi kehidupan masyarakat setempat berperan menjadi perekat diantara kelompok Islam dan Kristen. Oleh sebabnya, mereka sangat percaya dengan adat istiadat untuk menjaga persatuan dan kesatuan dengan menyebutnya sebagai sangkolan dari leluhur mereka.

\section{B. Taretan Dhibik}

Taretan dhibik juga merupakan istilah lain yang sering diungkapkan oleh masyarakat Sumberpakem dalam konteks kekeluargaan. Ini adalah bahasa Madura. Taretan artinya saudara, sementara dhibik artinya sendiri. Taretan dhibik mengandung arti saudara sendiri. Arti luas dari ungkapan ini adalah merujuk pada ikatan keluarga di waktu dan tempat yang berbeda. Kapanpun dan dimanapun, ketika mereka (masyarakat Madura) bertemu akan menyebut ungkapan ini. Dibalik ungkapan tersebut ada perasaan yang sama bahwa mereka berasal dari keluarga atau kebudayaan yang serupa. Atau setidak-tidaknya bahasa yang sama bahasa Madura. Karena itu, di Jawa Timur, khususnya di Surabaya, ungkapan ini sering menjadi klakar. Jika anda membeli barang kepada orang Madura, maka gunakanlah bahasa Madura. 
Harganya akan lebih murah. Ini karena mereka menganggap kita sebagai taretan dhibik.

Dalam kontek ini, taretan dhibik digunakan untuk menyebut masyarakat yang memiliki agama berbeda. Istilah ini menjadi semacam perekat bahwa mereka adalah saudara kita, entah ada hubungan darah-keluarga atau tidak. Mereka yang beragama lain bukan dianggap orang lain (the others), namun lebih dianggap sebagai saudara sendiri. Saudara bagi masyarakat Sumberpakem memiliki makna luas dan didalamnya mengandung ikatan sosial yang kuat, bahkan memiliki rasa emosional yang dalam. Ikatan sosial ini muncul karena mereka dibesarkan dalam lingkungan pedesaan dengan struktur yang sederhana. Mereka bercorak agraris dan memanfaatkan ekologi alam untuk memenuhi kebutuhan sehari-hari.

Dengan kondisi itu, setiap mereka memiliki solidaritas yang bersifat mekanik. Solidaritas itu memperlihatkan persatuan yang tinggi dan toleransi yang kuat akan perbedaan dan kepercayaan, termasuk perbedaan agama. Sekalipun ada perbedaan, mereka memiliki orientasi yang sama untuk mencapai tujuan hidup. Mereka terintegrasi karena ikatan yang menyatukan mereka kedalam komunitas yang sama pula. Menggunakan pemikiran Emile Durkheim, masyarakat di desa ini termasuk masyarakat mekanik yang memiliki kesadaran kolektif (collective consciousness), oleh sebab totalitas kepercayaan dan sentimen bersama yang ada pada masyarakat tersebut (Johnson, 1994 : 182-183).

Dalam konteks kehidupan sehari-hari, kesadaran kolektif itu dapat dilihat dari upaya mereka untuk menjaga persatuan dan kesatuan yang ditumbuhkan melalui komunikasi melintas batas. Komunikasi tersebut dapat disebut dengan dialog sosial. Dialog ini bukanlah dialog verbal, malainkan secara sosial. Dimensi dialog ini berupa etika dan spiritual. Etika dan spiritual esensinya tidak bisa diketahui, melainkan hanya bisa dirasakan melalui intensitas pengalaman spritual keagamaan. Diantara mereka (IslamKristen) diakui memiliki pemahaman yang sama bahwa etika dan spiritual itu hanya bisa dihayati oleh pelakunya (from within), bukan dilihat dari sudut pandang orang luar (from without). Di titik inilah mereka saling memahami dan percaya terhadap pengalaman hidup dan pengalaman religiusitasnya masing-masing. Sehingga secara sosiologis membentuk cara pandang mereka terhadap satu sama lainnya.

Dialog sosial yang lebih nyata adalah pada urusan kultural. Mereka saling melintas batas melalui praktek sosial. Diantara mereka bahkan merasa tak aneh ketika melakukan tindakan kultural yang sebetulnya menjadi tradisi agama lain. Sebagai contoh kunjung mengunjungi setelah sholat Idul Fitri (silaturrahmi). Sebagai seorang pendeta, Fajar Wicaksono mencerikatan bagaimana dia merasa dihormati dan diorangkan oleh masyarakat Islam. Dia dianggap tokoh agama yang juga harus dikunjungi (Fajar Wicaksono, 20 Juni 2017). Ketika sholat id selesai misalnya, dia harus diam di pastori (rumah dinas pendeta) untuk menerima kunjungan masyarakat Islam. Masyarakat datang berkelompok bersama keluarga dan anak-anaknya. Tak hanya itu, tokoh masyarakat dan tokoh agama juga datang ke rumah pendeta untuk meminta maaf dan saling berbincang dengan suasana yang gembira. Antara lain Pak Kampung, Pak Ustad Sofyan, Pak Fauzi sebagai tokoh Islam penting di desa itu.

Dalam hal ini yang menarik, pendeta itu harus menyiapkan jajan yang banyak. Beragam jajan telah dipersiapkan di rumah untuk menyambut masyarakat Islam yang berkunjung tersebut. Persiapan itu sama meriahnya dengan apa yang dilakukan masyarakat Islam ketika Idul Fitri tiba. Demikian juga, dia harus menyiapkan angpau (uang) untuk anak kecil, seperti lazimnya masyarakat ketika merayakan hari besar agamanya. Bahkan, sebelum masuk rumahnya, masyarakat Islam sudah lazim mengucapkan Assalamu'alaikum dan dia menjawabnya dengan wa'alaikum salam. Ungkapan itu tak membuat dia alergi. Kalimatkalimat yang umum diucapkan masyarakat Islam sudah terbiasa dilafalkan. Lalu dia bersalaman dan mengajak duduk sambil menanyakan kabar dan sebagainya. 
Untuk memperkuat silaturrahmi, beberapa hari setelah hari raya, Pendeta itu juga berkunjung ke rumah tokoh-tokoh masyarakat dan agama di atas. Dia disambut baik dan gembira layaknya menyambut kunjungan tokoh agama yang sama. Suasana gembira itu terjadi karena masyarakat merasa ingin bersaudara selamanya atau dalam istilah mereka disebut ataretan saterrosah. Praktek bebudayaan ini inklusif yang dilakukan tak hanya oleh tokoh agama, namun juga oleh setiap warga di desa ini. Bagi orang luar, mungkin ini adalah pemandangan yang anek. Tetapi bagi mereka, rindakan tersebut sudah membudaya. Mereka justru akan merasa tidak enak jika sholat id tanpa diikuti dengan bersilaturrahmi. Karena itu, dia merasa, sebagai seorang Pendeta yang tinggal di komunitas Islam merasa memiliki dua hari raya sekaligus, yakni Hari Raya Idul Fitri dan Hari Raya Natal. Inilah bentuk dialog sosial yang mereka lakukan hingga sekarang.

Dari cerita di atas, dapat dimengerti bahwa masyarakat di desa ini bisa membedakan mana urusan agama dan mana urusan budaya. Mereka tidak mencampuradukkan keduanya hanya untuk kepentingan toleransi. Budaya dan agama menjadi sangat berbeda. Namun dalam urusan kebudayaan, mereka merawatnya dengan mempraktekkan secara sosial. Semua itu terjadi karena mereka dibesarkan oleh komunitas yang sama dengan karakter kebudayaan yang sama pula. Kebudayaan yang dimaksud adalah pandhalungan yang tentu telah mempengaruhi cara berfikir mereka secara mendalam sebagaimana telah dijelaskan di atas. Kedua karena mereka memiliki struktur ekonomi dan pekerjaan yang sama. Mereka sama-sama agraris yang mengembangkan pertanian dan perkebunan sebagai cara untuk memenuhi kebutuhan hidup sehari-hari. Oleh karena itu, point penting dari penjelasan ini adalah masyarakat pandhalungan hadir sebagai entitas yang memiliki kebhinekaan (agama), namun mampu hidup bersama dengan mengelola perbedaan melalui kearifan lokal yang dimiliki. Kearifan lokal itu menjadi kunci yang mengikat mereka sebagai komunitas masyarakat yang tak lazim di tempat lain.

\section{PENUTUP}

Sebagai catatan penutup, dapat disimpulkan sebagai berikut; Pertama, etika masyarakat pandalungan dalam merajut kebhinnekaan (agama) ditunjukan dengan merawat peninggalan leluhur yang disebut dengan sangkolan. Sangkolan merupakan konsep yang berarti peninggalan yang merujuk pada cara bagaimana mereka seharusnya menjaga persatuan dan kesatuan, saling menghormati dan berbagi. Nilai-nilai yang terkandung dalam sangkolan itu adalah berupa cinta kepada Tuhan, tanggung jawab, kasih sayang dan peduli, adil dan saling menghormati. Sebagai sangkolan, antar masyarakat membangun komunitas yang setara tanpa ada sekat sosial. Mereka saling menyatu, bahkan melintas batas ((passing over). Melintas batas itu adalah bisa saling menyapa dalam konteks ritual kebudayaan. Seperti slametan, tahlilan dan sebagainya. Realitas ini bukan keanehan, melainkan sebagai ketakjuban bahkan sebagai cahaya Ilahi tentang keberagaman. Ini yang dimaksud dengan warisan leluhur yang tidak ditemukan pada masyarakat lain.

Kedua, untuk mempengaruhi kesadaran kolektif masyarakat, mereka memperkuat dengan istilah lokal yang disebut dengan Teretan Dhibik. Ini adalah istilah umum yang sering diungkapkan untuk mengatakan bahwa mereka yang beragama lain (Kristen atau Islam) adalah saudara kita. Mereka tidak menganggap masyarakat Islam atau Kristen adalah orang lain (the others). Sebutan ini efektif menjadi pengikat diantara masyarakat yang berbeda. Sehingga dalam praktek sehari-hari, mereka bisa berdialog secara sosial. baik keagamaan (abstrak) maupun kebudayaan (real). Dialog keagamaan berupa etika dan spiritual. Etika dan spiritual esensinya tidak bisa diketahui, melainkan hanya bisa dirasakan melalui intensitas pengalaman spritual keagamaan. Sementara dialog kebudayaan berupa praktek sosial kebudayaan, seperti silaturrahmi, tahlilan, dan slametan. Semua itu terjadi karena masyarakat dibesarkan oleh komunitas dan karakter kebudayaan yang sama, yakni kebudayaan pandhalungan. Selain itu, karena 
masyarakat juga memiliki struktur ekonomi dan pekerjaan yang sama. Mereka agraris dengan mengembangkan pertanian dan perkebunan sebagai cara untuk memenuhi kebutuhan hidup sehari-hari.

\section{DAFTAR RUJUKAN}

Fakih, Mansour, (2011). Jalan Lain; Manifesto Intelektual Organik. Yogyakarta. Pustaka Belajar

Hartono, Mudji. (2010). Migrasi Orang-Orang Madura Di Ujung Timur Jawa Timur: Suatu Kajian Sosial Ekonomi. ISTORIA Volume VIII Nomor 1.

Julailah. (2015). Keberadaan Greja Kristen Jawi Wetan (GKJW) Sumberpakem Kecamatan Sumberjambe Kabupaten Jember Tahun 1976 - 1999, Artikel Ilmiah Mahasiswa

Johnson, Doyle Paul, (1994). Teori Sosiologi Klasik dan Modern. Jakarta. PT Gramedia Purtaka Utama

Kristanto dan Wahyu, Kuali Peleburan di Tlatah Jawa Timur, Kompas, 21/7/2008

Mamuaya dan Sair, (2017). Toleransi Masyarakat Islam-Kristen Madura Di Desa Sumberpakem, Kecamatan Sumberjambe Kabupaten Jember. Madura, Jurnal Dimensi Volume 10 No. 2 Tahun 2017

Madjid, Nurcholish, dkk, (2017). Islam Universal. Yogyakarta. Pustakan Pelajar

Redaksi. (2008). Pengantar Jurnal Dialog Peradaban; Titik Temu. Volume 1 No 1 Tahun 2008

Setiawan, Ikwan. (2016). Mengapa (harus) Pendalungan? Konstruksi dan kepentingan Dalam Penetapan Identitas Jember. Makalah
Sihombing. (2009) Sejarah Gereja di Indonesia, Diktat, Sekolah Tinggi Teologi HKBP Pematangsiantar

Sutarto. (2006). Sekilas Tentang Masyarakat Pndhalungan. Makalah disampaikan pada acara pembekalan Jelajah Budaya 2006 yang diselenggarakan oleh Balai Kajian Sejarah dan Nilai Tradisional Yogyakarta, tanggal 7 - 10 Agustus 2006

Turmudi, Endang. (2004). Perselingkuhan Kiai dan Kekuasaan. Yogyakarta. LKiS

Vlekke, Bernard, HM. (2018). Nusantara; Sejarah Indonesia. Jakarta. Kepustakaan Populer Gramedia. Hal 316

Wibisono dan Haryono (2016). Wacana Perkawinan di Tapal Kuda. Jember. Tapal Kuda

Zoebazary, M. Ilham. (2017). Orang Pendalungan: Penganyam Kebudayaan di Tapal Kuda. Jember. Paguyupan Pandhalungan Jember.

\section{Internet}

https://nasional.tempo.co/read/719535/ini-10kota-paling-toleran-di-indonesia, diakses pada tanggal 1 Agustus 2017

https://www.worldometers.info/worldpopulation/, diakses pada tanggal 13 Agustus 2019

https://id.m.wikipedia.org/wiki/Sejarah Kristen di Madura, diakses pada tanggal 3 Agustus 2017

www.gkjwbondowoso.blogspot.co.id, pada tanggal 5 Agustus 2017 